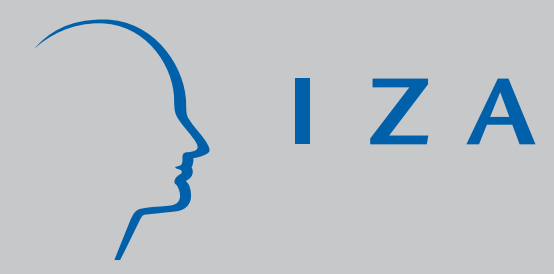

IZADP No. 4063

\title{
Can Profit Sharing Lower Flexible Outsourcing?
} A Note

Erkki Koskela

J an König

March 2009 


\title{
Can Profit Sharing Lower Flexible Outsourcing? A Note
}

\author{
Erkki Koskela \\ University of Helsinki \\ and IZA \\ Jan König \\ Free University Berlin
}
Discussion Paper No. 4063
March 2009

\author{
IZA \\ P.O. Box 7240 \\ 53072 Bonn \\ Germany \\ Phone: +49-228-3894-0 \\ Fax: +49-228-3894-180 \\ E-mail: iza@iza.org
}

\begin{abstract}
Any opinions expressed here are those of the author(s) and not those of IZA. Research published in this series may include views on policy, but the institute itself takes no institutional policy positions.

The Institute for the Study of Labor (IZA) in Bonn is a local and virtual international research center and a place of communication between science, politics and business. IZA is an independent nonprofit organization supported by Deutsche Post Foundation. The center is associated with the University of Bonn and offers a stimulating research environment through its international network, workshops and conferences, data service, project support, research visits and doctoral program. IZA engages in (i) original and internationally competitive research in all fields of labor economics, (ii) development of policy concepts, and (iii) dissemination of research results and concepts to the interested public.
\end{abstract}

IZA Discussion Papers often represent preliminary work and are circulated to encourage discussion. Citation of such a paper should account for its provisional character. A revised version may be available directly from the author. 
IZA Discussion Paper No. 4063

March 2009

\section{ABSTRACT \\ Can Profit Sharing Lower Flexible Outsourcing? A Note*}

We analyze the following question associated with flexible outsourcing under imperfect domestic labour market: How does the implementation of profit sharing influence flexible outsourcing? We show that in general profit sharing has a negative effect on low skilled wage and thus an outsourcing decreasing character. However due to labour union determination of effort a constant effort level will result so that in this case firm's optimal choice of profit sharing is zero.

JEL Classification: E24, J23, J33, J51, J82

Keywords: flexible outsourcing, profit sharing, labour market imperfection

Corresponding author:

Erkki Koskela

Department of Economics

University of Helsinki

P.O. Box 17 (Arkadiankatu 17)

$\mathrm{FI}-00014$

Finland

E-mail: erkki.koskela@helsinki.fi

\footnotetext{
* The authors thank Academy of Finland (grant No. 1117698) for financial support. Koskela thanks Freie Universität Berlin for great hospitality and König thanks University of Helsinki for great hospitality.
} 


\section{Introduction}

In an integrated world, marginal cost differences are the driving force for the reallocation of production parts (offshoring) and for the make-or-buy-decision (outsourcing). Especially for western European countries, the wage and labour cost differences constitute the central explanation for the increasing business practice of offshoring and international outsourcing to eastern European or Asian countries. ${ }^{1}$ Reasons for the wage gaps are, among others, differences in labour market institutions and in the process of wage determination. In most western European countries, wages are determined by bilateral bargaining between firms or employer federations and trade unions. In eastern European or Asian countries, however, unions are much weaker so that wages are determined by market forces (see e.g. Du Caju et al. (2008)).

Concerning the analysis of the effect of outsourcing on compensation schemes under wage bargaining there are two focuses in the literature, the case of committed outsourcing and flexible outsourcing. While in the committed case outsourcing takes place before wage bargaining ${ }^{2}$, in the flexible case outsourcing is decided after wage bargaining. Our focus in this paper is to assume that outsourcing is flexible, i.e. determined simultaneously with domestic labour demand and after wage formation. ${ }^{3}$ Skaksen (2004) has analyzed the implications of outsourcing for wage setting and employment under imperfectly competitive labour markets in terms of both potential (non-realized) and realized international outsourcing. By assuming that output is produced by combining two intermediate activities, where one activity can be perfectly substituted by outsourcing, he shows that the wage level depends on

$1 \quad$ See Amiti and Wei (2005) and Rishi and Saxena (2004), which emphasize the big difference in labour costs as the main explanation for the strong increase in outsourcing of both manufacturing and services to countries with low labour cost.

2 See e.g. Perry (1997) for an overview about the relationship between outsourcing and wage bargaining. Also e.g. Danthine and Hunt (1994), Zhao (2001) and Koskela and Stenbacka (2009) have analyzed committed outsourcing issue.

3 There are also some new analyses, which incorporated flexible outsourcing and wage bargaining, e.g. Koskela and Poutvaara (2008) or Koskela (2008). But the main focuses in these papers are labour taxation issues in the absence of profit sharing. 
outsourcing cost. If these costs are under a lower bound, the union will desist from wage dumping to avoid outsourcing. Are the cost over a critical value, there is no outsourcing and the union can set relative high wage level. For intermediate cost level, external procurement can prevent by setting domestic wage level equal to outsourcing cost. Also, Braun and Scheffel (2007) have developed a simple two-stage game between a monopoly union and a firm by assuming that the union sets wages before the firm decides on the degree of outsourcing and the level of production. They argued that under such flexible outsourcing the costs of outsourcing have an ambiguous effect on the wage set by the labour union. But in these papers they have abstracted from the analysis of profit sharing as a part of the compensation scheme and bargaining over effort, which is our focus.

The threat of flexible outsourcing as a reaction to high domestic marginal production cost will dampen the opportunity of the trade union to realize a high wage level. To induce them to abstain from external procurement of intermediate goods, western European firms need lower marginal cost. But if lower costs are not possible, then firms have to increase productivity of domestic production, which is influenced by workers' effort. One way to stimulate effort is profit sharing. ${ }^{4}$ The idea behind the implementation of profit sharing is that this will induce incentives to increase effort and thus productivity for given wage level, while the climate in a firm will be improved. ${ }^{5}$ However, profit sharing can also affect the wage formation, which could lead to a lower base wage since a part of the former wage level is substituted by profit income. Since only the base wage enters marginal cost, in this case outsourcing will decrease, ceteris paribus. The biggest problem of firm's owner is to solve the moral hazard problem and to verify the individual effort. In the literature of efficiency wage

$4 \quad$ Empirical studies show that profit sharing is an important phenomenon in many OECD countries. Pendleton et al. (2001) have presented detailed data on profit sharing schemes in 14 OECD countries. See also Conyon and Freeman (2001).

$5 \quad$ Introducing a profit sharing scheme can increase the motivation of a worker and thus effort, see Cable and Fitzroy (1980). On the other side Jones and Pliskin (1991) and Kruse (1993) find negative productivity effects of profit sharing. 
models ${ }^{6}$, this is solved with paying a higher wage than the competitive level, but effort can also be interpreted as working condition such as speed of production line and so be a part of wage negotiations. In that case, the literature is mainly focusing on comparison of effort level set by union and in a competitive market, analysis of the effect of bargaining power on effort level and efficiency properties. ${ }^{7}$ Also the implementation of profit sharing schemes is analyzed with collective bargaining. Pohjola (1987) and Anderson and Devereux (1989) show that efficient but unenforceable bargaining outcome, because direct negotiation on the total employment is precluded, can be made enforceable by introducing bargaining over wages and profit share. Additional Anderson and Devereux (1989) show that for efficient bargaining over wages and employment implementing profit sharing has no effect on wages, employment and profit both when profit sharing is exogenously increased by legislator and when profit sharing is a part of the optimal contract.

In this paper we use the approach of union setting wage and effort, while the firm set the profit share to analyze: How does profit sharing influence flexible outsourcing? By knowing this we can also show due to comparative statics, how does outsourcing influence the wage level? The analysis shows that the union sets an effort level, which is unaffected by wage and profit sharing. However profit sharing can decrease the wage and thus outsourcing. For the optimal profit share we find an earlier result, that the firm won't implement any profit sharing scheme. For our minor question we find, that in the presence of outsourcing due to a more elastic labour demand the base wage is lower than in the absence of outsourcing.

$6 \quad$ See Salop (1979) and Shapiro and Stiglitz (1984) as the standard models. For a survey, see Akerlof and Yellen (1986), where they mentioned (i) shirking models, (ii) labour turnover models, (iii) adverse selection models and (iv) sociological models in their book, which includes the main initial papers associated with these original important efficiency wage models.

$7 \quad$ Bulkley (1992) has shown that a monopoly union will reduce the specified effort level below that which would be demanded by the firm in its absence. Moreover, Bulkley and Myles (1996) showed that the popular wisdom that unions reduce effort is generally false. The effect of bargaining power if effort is negotiable have been also analyzed by Sampson (1993) and Bulkley and Myles (1997). They showed that in a generalized Nash bargaining between a union and a firm over employment and effort higher bargaining power of the firm can increase the effort level. 
We proceed as follows. The basic structure of the theoretical framework is briefly presented in section 2 . In section 3 we derivate the optimal labour and outsourcing demand. Section 4 investigates the effort and wage formation by the monopoly trade union. Finally, we sum our conclusions in section 5.

\section{The Basic Framework}

We assume that output depends not only on domestic labour and international outsourcing, but also on the average effort by workers, i.e. the workers' productivity. This lies in conformity with the efficiency wage hypothesis form. ${ }^{8}$ The timing captures the idea that the representative firm is flexible to decide about the amount of outsourcing simultaneously with domestic labour demand, but commits to profit sharing before wage and effort determination. After the firm has decided about profit sharing, the monopoly trade union sets the wage and effort with respect to the profit share level. Knowing the base wage, the representative firm determines outsourcing and employment. The timing of events is depicted as Figure 1.

Figure 1: Time sequence

\begin{tabular}{lll} 
Stage 1 & Stage 2 & Stage 3 \\
\hline profit & wage and effort & outsourcing $M$, \\
sharing $\tau$ & formation $w$, & labour demand $L$
\end{tabular}

The decisions at each stage are analyzed by using backward induction.

\section{Optimal Outsourcing and Labour Demand}

$8 \quad$ See e.g. the book edited by Akerlof and Yellen (1986). 
In this section we characterize the optimal labour demand and outsourcing by the representative firm by taking profit sharing, wage and effort as given. The revenue function is presented as

$$
R(L, M)=\frac{\delta}{\delta-1}(e L+M)^{\frac{\delta-1}{\delta}}, \text { with } \delta>1
$$

where the price of the output is normalized to unity, $L$ is the amount of domestic labour, $e$ characterize the average effort level, and $M$ is the firm's labour input acquired from external suppliers through outsourcing. ${ }^{9}$ The parameter $\delta>1$ means that the production function is an increasing and concave function of inputs. ${ }^{10}$ Here we assume that there is a perfect substitutability between domestic labour and outsourcing.

The firm decides on domestic labour and outsourcing to maximize the profit function

$$
\underbrace{\operatorname{Max}}_{(L, M)} \pi=\frac{\delta}{\delta-1}(e L+M)^{\frac{\delta-1}{\delta}}-w L-\frac{1}{2} c M^{2},
$$

by taking the negotiated effort, $e$, wage, $w$, and profit sharing, $\tau$, as given. We assume that the costs of outsourcing are convex to represent the establishing capacity for foreign outsourced activity so that the marginal cost of outsourcing increases in

9 We following the efficiency wage literature and assume that effort is labour augmenting. In what follows, $e L$ can be interpreted as effective labour.

10 This paper does not focus on the simultaneous presence of imperfections in labor and product markets so that in this model the wage-moderating effect of outsourcing is independent of potential market structure change in the product market. Lommerud et al. (2006) have demonstrated how international mergers might curb the market power of unions giving socially excessive incentive for international mergers, unless products are close substitutes. A somewhat related wage-moderating effect of foreign investments is developed in Eckel and Egger (2006). They focus on duopoly competition within a framework where the firms can produce either in one or both of two identical countries. Within such a framework foreign market penetration induces a wage-moderating effect in a unionized economy, because it improves the firm's outside option relevant for the wage negotiations. 
the scope of activities to outsource. The first-order conditions $\pi_{L}=e \cdot(e L+M)^{-\frac{1}{\delta}}-w=0$ and $\pi_{M}=(e L+M)^{-\frac{1}{\delta}}-c M=0$ can be expressed as

$$
\begin{aligned}
& L=w^{-\delta} e^{\delta-1}-\frac{M}{e}=w^{-\delta} e^{\delta-1}-\frac{w}{c e^{2}}, \\
& M=\frac{w}{c e} .
\end{aligned}
$$

Domestic labour demand is a negative function of wage and the amount of outsourcing and a positive function of both outsourcing cost and effort. Higher outsourcing will decrease domestic labour demand, which lies in conformity with empirics $^{11}$ and results of our assumption of substitutability. However, labour demand does not directly depend on profit sharing, which lies also in conformity with empirical evidence. ${ }^{12}$ For outsourcing we found that the external procurement is a positive function of domestic wage rate and a negative function of both outsourcing cost and effort. In the case of revenue function (1) the direct reactions could be described by the outsourcing elasticities in terms of outsourcing cost, effort and wage as follows: $\frac{M_{c} c}{M}=\frac{M_{e} e}{M}=-1$ and $\frac{M_{w} w}{M}=1$.

The direct wage elasticity of labour demand, which turns out to be important later on, can be expressed as

$$
\eta \equiv-\frac{L_{w} w}{L}=\left[\delta+(1+\delta) \frac{M}{e L}\right]
$$

The wage elasticity depends on parameter $\delta$ and also on wage rate and outsourcing cost via $M$ and $L$ which we present in section 4 . In the absence of outsourcing the wage elasticity is constant and smaller, i.e. $\left.\eta\right|_{M=0}=\bar{\eta}=\delta<\eta$. 


\section{Wage and Effort Formation by Monopoly Labour Union}

Since the individual worker has no impact on profit, the dominant strategy is to provide only a minimum level of effort, i.e. shirking. As we mention in the introduction, effort could be understand as working condition, which can be determined in bargaining rounds between trade union and firms. In this analysis we assume a simultaneous setting of wage and effort by the employee federation.

\subsection{Wage and Effort Determination}

The individual utility function for the employed worker is (5a) and for the unemployed worker (5b)

$$
\begin{aligned}
& v=w+\frac{\tau}{L} \pi-g(e), \\
& \bar{v}=b,
\end{aligned}
$$

so that utility is assumed to be linear in income. In addition we assume that provision of the effort is associated with a disutility for the worker, which is assumed to satisfy the following convex function $g(e)=\gamma e^{1 / \gamma}$ with $0<\gamma<1$, i.e. $g^{\prime}(e), g^{\prime \prime}(e)>0$.

The monopoly labour union is assumed to interested in income of union member, so that the objective function is $V=v L+(N-L) \bar{v}$. So we can rewrite the union utility as

$$
\underbrace{\operatorname{Max} V}_{(w, e)}=(w-b) L+\tau \pi-g(e) L+b N \text { s.t. } \pi_{L}=\pi_{M}=0
$$

where $b$ captures the exogenous minimum income for labour union members $N$. 
Maximizing in terms of the base wage and effort subject to labour demand and outsourcing gives

$$
V_{w}=L+L_{w}(w-b)+\tau \pi_{w}-g(e) L_{w}=0,
$$

which can be solved as $w[\eta-(1-\tau)]=\eta(b+g)$, so that we have

$$
w=\left[\frac{\eta}{\eta+\tau-1}\right](b+g)
$$

This is an implicit form concerning wage formation, because both the nominator and denominator of the mark-up depend in a non-linear way on the wage rate according to equation (4).

The first order condition for the optimal effort level is

$$
V_{e}=L_{e}(w-b)+\tau \pi_{e}-g(e) L_{e}-L g^{\prime}(e)=0 .
$$

By using $\pi_{e}=\frac{w}{e} L$ and $\frac{L_{e} e}{L}=\eta-1$ the first order condition (9) can be expressed as follows

$$
w=\left[\frac{\eta-1}{\eta+\tau-1}\right](b+g)+\frac{e^{1 / \gamma}}{\eta+\tau-1} .
$$

A simultaneous solution of (8) and (10) gives the optimal effort

$$
e=\left[\frac{b}{1-\gamma}\right]^{\gamma}
$$


Our analysis shows that optimal effort level decided by the monopoly trade union is independent of profit share or base wage.

Thus we can conclude that profit sharing does not affect effort provision and so it does not increase productivity. However, we also mention that implementing profit sharing can have a wage moderation effect. Since higher wages increase external procurements, we have to show the impact of profit sharing on base wage to answer our research question and show the impact of profit sharing on outsourcing.

From equation (8) and (11) follows that profit sharing has only a direct effect, which can be seen in the denominator. This effect we call substitution effect, since this effect will decrease the base wage, which means that a former part of the base wage is substituted by profit income. The same holds in the case of no outsourcing. Analytical this can be shown by using the total differential of (8)

$$
\frac{d w}{d \tau}=-\frac{w}{\eta+\tau-1+(1-\tau) \eta_{w} w / \eta}<0
$$

with $\eta_{w}=(1+\delta)\left[\frac{e L M_{w}-e M L_{w}}{(e L)^{2}}\right]$ which gives $\eta_{w}=(1+\delta) \frac{M}{w e L}(1+\eta)>0$. Although, we find that profit sharing has a complementary character for the base wage, in the empirical literature there is also evidence for a supplementary property of profit sharing. ${ }^{13}$ In the absence of outsourcing, we have $\left.\eta_{w}\right|_{M=0}=0$, so that base wage does not affect the wage elasticity of labour demand. In that case we get qualitatively the same result $\left.\frac{d w}{d \tau}\right|_{M=0}=-\frac{\left.w\right|_{M=0}}{\delta+\tau-1}<0$.

In a similar way we can also look at the wage reaction concerning changes in outsourcing cost. The reaction of the wage elasticity is described by

13 Black and Lynch (2000) show by using U.S. data, that profit sharing results in lower regular pay for workers, which implies a compensatory character, but in Wadhwani and Wall (1990) by using UK data and also in Kraft and Ugarkovic (2005) by using German panel data, it has been shown that introducing profit sharing does not reduce the wage, which implies a supplementary character. 
$\eta_{c}=(1+\delta)\left[\frac{e L M_{c}-M e L_{M} M_{c}}{(e L)^{2}}\right]$ so that we have $\eta_{c}=-(1+\delta) \frac{M}{c e L}\left(1+\frac{M}{e L}\right)<0$

Higher outsourcing cost will decrease the wage elasticity of labor demand and will reduce ceteris paribus the demand of outsourcing, which leads to a decrease of the ratio of outsourcing and effective labour, which makes the labour demand more inelastic. ${ }^{14}$ Thus the wage effect of changing outsourcing cost is

$$
\frac{d w}{d c}=-\frac{(1-\tau) \eta_{c} w / \eta}{(\eta-1+\tau)+(1-\tau) \eta_{w} w / \eta}>0
$$

so that lower outsourcing cost in the presence of flexible outsourcing will lower the wage. This holds, since lower outsourcing cost means for given wage level higher outsourcing demand, so that the labour demand elasticity becomes more elastic and therefore the wage has to fall, since the trade union can avoid higher outsourcing with lower in-house cost and make integrated production more attractive. ${ }^{15}$

We can summarize our findings in

Proposition 1: In the presence of flexible outsourcing,

a) union bargaining over effort is unaffected by base wage and profit sharing, and

b) profit sharing is compensating part of income, and

c) lower outsourcing cost will lower the wage.

Now, we analyze the effect of implementing profit sharing in a firm which engages in outsourcing. The working channel of committed profit sharing on the amount of

$14 \quad$ See e.g. Hasan et al. (2007), Slaughter (2001) and Senses (2006).

15 This lies in conformity with empirics according to which there is substitutability between outsourcing and domestic labour (see e.g. Munch and Skaksen (2009)). 
outsourcing is $\frac{d M}{d \tau}=\frac{\partial M}{\partial w} \cdot \frac{d w}{d \tau}$. Inserting the different expression and simplifying yields

$$
\frac{d M}{d \tau}=\frac{1}{c e} \cdot \underbrace{\frac{d w}{d \tau}}_{-}<0,
$$

so that the effect of implementing profit sharing is negative. In the case of a complementary character of profit sharing, implementing profit sharing will reduce the demand for outsourcing. This relationship is intuitive for the following reason. Higher profit sharing will decrease the base wage. Since only the base wage enters the marginal cost, the advantage of integrated production increases by inducing a higher labour demand. In this case, the amount of outsourcing will be lower with higher profit sharing. Since effort level is constant, only this wage reduction channel induces lower outsourcing by substituting wage income by profit income so that we have

Proposition 2: In general profit sharing decreases marginal cost, so that outsourcing activities are decreasing.

\subsection{Committed Profit Sharing}

The representative firm commits to profit sharing to maximize profit subject to labour demand (3a), outsourcing (3b), effort determination (11) and wage formation (8) so that

$$
\begin{aligned}
\underset{\tau}{\operatorname{Max}} \bar{\pi} & =(1-\tau)\left[\frac{\delta}{\delta-1}(e L+M)^{\frac{\delta-1}{\delta}}-w L-\frac{1}{2} c M^{2}\right] \quad \text { s.t. } \\
L & =w^{-\delta} e^{\delta-1}-\frac{M}{e}=w^{-\delta} e^{\delta-1}-\frac{w}{c e^{2}}
\end{aligned}
$$




$$
\begin{aligned}
& e=\left(\frac{b}{1-\gamma}\right)^{\gamma} \\
& w=\frac{\eta}{\eta-1+\tau}(b+g(e)) .
\end{aligned}
$$

The first-order condition is $-\pi+(1-\tau) \pi_{\tau}=0$, where $\pi$ is the indirect profit. The first derivative with respect to profit sharing is $\pi_{\tau}=-w_{\tau} L$. Using the known terms, the first-order condition yields the optimal committed profit sharing in the presence and absence of outsourcing, i.e.

$$
\tau=\frac{\pi}{w_{\tau} L}+1
$$

In the absence of outsourcing this expression can be rewritten to $\left.\tau\right|_{M=0}=\frac{w L-(\delta-1) \pi}{w L+\pi}$, where the nominator is zero, since $\pi=\frac{w L}{\delta-1}$. This implies $\left.\tau\right|_{M=0}=0$. In the presence of outsourcing the optimal profit share expression is more complicated, but it can be shown that $\left.\tau\right|_{M>0}<0$, so that the firm also desist from profit sharing.

We can summarize our findings in

Proposition 3: If the trade union sets effort level, the firm desists from profit sharing.

This is reasonable since the worker will only provide the effort level setting by the union, which is independent of remunerations. The provision of this level is the dominate strategy for an individual worker, because he/she has no influence on the firm's profit. Since the decision about effort provision is unchanged, even if the firm will set some incentives by introducing profit sharing, the firm will only contribute a part of profit to the worker without effects on effort or profit. Thus, it is beneficial for 
the firm to avoid profit sharing. The same argumentation holds if the firm doesn't engage in outsourcing. Although profit sharing can decrease the wage, a firm will abandon from this instrument, since due to outsourcing there is also a wage moderation effect. Since the firm doesn't care about using domestic labour or outsourcing, there is no incentive to implement profit sharing for reducing the wage and lower amount of profit the firm owner gets.

So we can answer our question as follows: If the union set the effort level, profit sharing in general will decrease outsourcing demand. However a profit maximizing firm will abstain from profit sharing, since it creates no enhancing productivity effect. Thus there is also no wage moderation, so that profit sharing has no influence on outsourcing demand.

Knowing the optimal effort level, we can due to comparative statics give a statement about the wage effect of outsourcing. Since in the absence and presence of outsourcing the effort level is the same, we have only focusing on the mark-up $A=\frac{\eta}{\eta-1}$ with $\eta=\delta+(\delta+1) \frac{M}{e L}$ and $\left.\eta\right|_{M=0}=\delta<\eta$. Since the mark-up is decreasing with higher labour demand elasticity it follows that $w<\left.w\right|_{M=0}$. This we can sum to

Proposition 4: Outsourcing has a wage decreasing effect.

This holds, since higher outsourcing demand results from lower outsourcing cost. As we have shown in (13) this reduce the base wage due to a more elastic labour demand. So setting a high wage increases the loss for the union leads and leads to a less aggressive union behavior what results in a lower wage. Hereby the union can avoid outsourcing and make integrated production more attractive.

\section{Conclusions}


We have focused on the question: How does profit sharing influence flexible outsourcing? In our framework we show, that the union setting effort level is independent of profit sharing. So only a wage moderation effect can occur if implementing a profit sharing scheme. Since outsourcing and domestic labour are substitutes this wage effect leads to lower outsourcing. So, in general implementing profit sharing can lead to lower outsourcing due to the wage effect. However, the optimal profit share is zero, since implementing profit sharing does not increase effort. Moreover, we also showed that lower outsourcing cost and thus higher outsourcing will decrease the base wage.

\section{References:}

Akerlof, G.A. and J. L. Yellen (1986) (eds): Efficiency Wage Models of the Labor Market, Cambridge University Press, MA.

Amiti, M. and S.-J. Wei (2005): Fear of Service Outsourcing: Is It Justified?, Economic Policy 20, 307-347.

Anderson, S. and M. Devereux (1989): Profit - Sharing and Optimal Labour Contracts, Canadian Journal of Economics 22, 425-433.

Black, S. E. and L.-M. Lynch (2000): What's Driving the New Economy: The Benefits of Workplace Innovation, NBER Working Paper 7479.

Braun, S. and J. Scheffel (2007): A Note on the Effect of Outsourcing on Union Wages, SFB Discussion Paper 2007-034, Humbold Universität zu Berlin.

Bulkley, G. (1992): Does a Trade Union Set a Lower Effort Level Than would Be Determined in a Competitive Labour Market?, Bulletin of Economic Research 44, 153-160.

Bulkley, G. and G. D. Myles (1996): Trade Unions, Efficiency Wages, and Shirking, Oxford Economic Paper 48, 75-88.

Bulkley, G. and G. D. Myles (1997): Bargaining over Effort, European Journal of Political Economy 13, 375-384. 
Cable, J. R. and F. R. Fitzroy (1980): Cooperation and Productivity: Some Evidence from West Germany's Experience, Economic Analysis and Workers Management 14, 163-190.

Cahuc, P. and B. Dormont (1997): Profit Sharing: Does It Increase Productivity and Employment? A Theoretical Model and Empirical Evidence on French Micro Data, Labour Economics 4, 293-319.

Conyon, M. and R. Freeman (2001): Shared Modes of Compensation and Firm Performance: UK Evidence, NBER Working Paper No. 8448.

Danthine, J.-P. and J. Hunt (1994): Wage Bargaining Structure, Employment and Economic Integration, Economic Journal 104, 528-541.

Du Caju, P., E. Gautier, D. Momferatou and M. Ward-Warmedinger (2008): Institutional Features of Wage Bargaining in 23 European Countries, the US and Japan, IZA DP No. 3867, December 2008.

Eckel, C. and H. Egger (2006): Wage Bargaining and Multinational Firms in General Equilibrium, CESifo Working Paper No. 1711.

Görg, H. and A. Hanley (2005): Labor Demand Effects of International Outsourcing: Evidence from Plant-Level Data, International Review of Economics and Finance 14, 365-376.

Hasan, R., D. Mitra and R.W. Ramaswamy (2007): Trade Reforms, Labor Regulations, and Labor-Demand Elasticities: Empirical Evidence from India, the Review of Economics and Statistics, 89(3), 466-481.

Jones, D. C. and J. Pliskin (1991): The Productivity Effects of Profit Sharing and Worker Representation on the Board, Working Paper Hamilton College No. 91.

Koskela, E. (2008): The Effects of Labour Tax Progression under Nash-Bargaining and Flexible Outsourcing, IZA Discussion Paper No. 3501.

Koskela, E. and P. Poutvaara (2008): Flexible Outsourcing and the Impacts of Labour Taxation Progression in European Welfare States, HECER Discussion Paper No. 229.

Koskela, E. and R. Stenbacka (2009): Equilibrium Unemployment with Outsourcing under Labour Market Imperfections, forthcoming in: Labour Economics.

Kraft, K. and M. Ugarkovic (2005): Profit-Sharing: Supplement or Substitute?, Dortmund University, Germany.

Kruse, D. (1993): Does Profit Sharing Affect Productivity?, NBER Working Paper No. 4542. 
Lommerud, K. E., F. Meland and L. Sorgard (2006): National versus International Mergers in Unionized Oligopoly, Rand Journal of Economics 37, 212-233.

Munch, J. R. and J. R. Skaksen (2009): Specialization, Outsourcing and Wages, IZA Discussion Paper No. 1907, forthcoming in: Review of World Economics.

Pendleton, A., E. Poutsma, J. van Ommeren and C. Brester (2001): Employee Share Ownership and Profit Sharing in the European Union, Office for Official Publications of the European Commission, Luxembourg.

Perry, C. R. (1997): Outsourcing and Union Power, Journal of Labor Research 18, 521-534.

Pohjola, M. (1987): Profit-Sharing, Collective Bargaining and Employment, Journal of Institutional and Theoretical Economics 143, 334-342.

Rishi, M. and S. C. Saxena (2004): Is Outsourcing Really as Bad as It Is Made Sound? A Re-assessment and Some Perspective, Working Paper University of Pittsburgh.

Salop, S. (1979): A Model of Natural Rate of Unemployment, American Economic Review 69, 117-125.

Sampson, A. A. (1993): Bargaining over Effort and the Monitoring Role of Unions, European Journal of Political Economy 9, 371-381.

Shapiro, C. and J. E. Stiglitz (1984): Equilibrium Unemployment as a Worker Discipline, American Economic Review 74, 433-444.

Senses, M. Z. (2006): The Effects of Outsourcing on the Elasticity of Labor Demand, CES Discussion Paper, Washington D.C., March.

Slaughter, M. (2001): International Trade and Labor-Demand Elasticities, Journal of International Economics 54, 27-56.

Skaksen, J. R. (2004): International Outsourcing When Labor Markets Are Unionized, Canadian Journal of Economics 37(1), 78-94.

Wadhwani, S. and M. Wall (1990): The Effects of Profit Sharing on Employment, Wages, Stock Returns and Productivity: Evidence from U.K. Micro Data, Economic Journal 100, 1-17.

Zhao, L. (2001): Unionization, Vertical Structure, and the Outsourcing of Multinationals, Journal of International Economics 55, 187-202. 